\title{
Publisher Correction: Desumoylase SENP6 maintains osteochondroprogenitor homeostasis by suppressing the p53 pathway
}

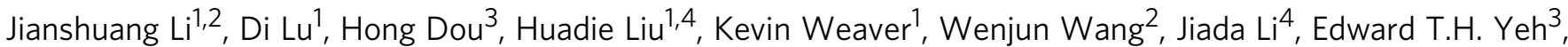
Bart O. Williams', Ling Zheng ${ }^{2} \&$ Tao Yang (1) ${ }^{1}$

Correction to: Nature Communications https://doi.org/10.1038/s41467-017-02413-3, published online 2 November 2017

In the originally published version of this Article, the positions of the final two authors in the author list were inadvertently inverted during the production process. This error has now been corrected in both the PDF and HTML versions of the Article.

Published online: 08 February 2018

\begin{abstract}
(c) (i) Open Access This article is licensed under a Creative Commons Attribution 4.0 International License, which permits use, sharing, adaptation, distribution and reproduction in any medium or format, as long as you give appropriate credit to the original author(s) and the source, provide a link to the Creative Commons license, and indicate if changes were made. The images or other third party material in this article are included in the article's Creative Commons license, unless indicated otherwise in a credit line to the material. If material is not included in the article's Creative Commons license and your intended use is not permitted by statutory regulation or exceeds the permitted use, you will need to obtain permission directly from the copyright holder. To view a copy of this license, visit http://creativecommons.org/licenses/by/4.0/.
\end{abstract}

(C) The Author(s) 2018

\footnotetext{
${ }^{1}$ Center for Cancer and Cell Biology, Van Andel Research Institute, Grand Rapids, MI 49503, USA. ${ }^{2}$ Hubei Key Laboratory of Cell Homeostasis, College of Life Sciences, Wuhan University, Wuhan, 430072 Hubei, China. ${ }^{3}$ Center for Precision Medicine, Department of Medicine, University of Missouri, Columbia, MO 65212, USA. ${ }^{4}$ State Key Laboratory of Medical Genetics and School of Life Sciences, Central South University, Changsha, 410078 Hunan, China.

Correspondence and requests for materials should be addressed to L.Z. (email: Izheng@whu.edu.cn) or to T.Y. (email: tao.yang@vai.org)
} 